\title{
Archaeal distribution and abundance in water masses of the Arctic Ocean, Pacific sector
}

\author{
Chie Amano-Sato ${ }^{1}$, Shohei Akiyama ${ }^{1}$, Masao Uchida $^{2}$, Koji Shimada $^{3}$, \\ Motoo Utsumi ${ }^{1, *}$ \\ ${ }^{1}$ University of Tsukuba, Tennodai, Tsukuba, Ibaraki 305-8572, Japan \\ ${ }^{2}$ National Institute for Environmental Studies, Onogawa, Tsukuba, Ibaraki 305-8506, Japan \\ ${ }^{3}$ Tokyo University of Marine Science and Technology, Konan, Minato-ku, Tokyo 108-8477, Japan
}

\begin{abstract}
Marine planktonic Archaea have been recently recognized as an ecologically important component of marine prokaryotic biomass in the world's oceans. Their abundance and metabolism are closely connected with marine geochemical cycling. We evaluated the distribution of planktonic Archaea in the Pacific sector of the Arctic Ocean using fluorescence in situ hybridization (FISH) with catalyzed reporter deposition (CARD-FISH) and performed statistical analyses using data for archaeal abundance and geochemical variables. The relative abundance of Thaumarchaeota generally increased with depth, and euryarchaeal abundance was the lowest of all planktonic prokaryotes. Multiple regression analysis showed that the thaumarchaeal relative abundance was negatively correlated with ammonium and dissolved oxygen concentrations and chlorophyll fluorescence. Canonical correspondence analysis showed that archaeal distributions differed with oceanographic water masses; in particular, Thaumarchaeota were abundant from the halocline layer to deep water, where salinity was higher and most nutrients were depleted. However, at several stations on the East Siberian Sea side of the study area and along the Northwind Ridge, Thaumarchaeota and Bacteria were proportionally very abundant at the bottom in association with higher nutrient conditions. The abundance of Euryarchaeota was high $(>1.0 \times$ $10^{5} \mathrm{cells} \mathrm{ml}^{-1}$ ) at one of our stations in the Chukchi Sea and was positively correlated with temperature and ammonium concentration, suggesting that there could be 'hot spots' with increased euryarchaeal abundance in the Arctic Ocean.
\end{abstract}

KEY WORDS: Arctic marine environment $\cdot$ Biogeographical distribution $\cdot$ CARD-FISH $\cdot$ Marine Archaea $\cdot$ Marine microbial ecology $\cdot$ Prokaryotes

\section{INTRODUCTION}

Planktonic marine Archaea were first reported in the mesopelagic layer of the Pacific Ocean on the basis of archaeal 16S rRNA gene sequences (Fuhrman et al. 1992). At the same time, DeLong (1992) carried out a quantitative molecular survey using fluorescence in situ hybridization (FISH) specific for marine prokaryotes and determined the presence and abundance of 2 planktonic marine archaeal groups: Crenarchaeota and Euryarchaeota. Recently, the genome sequence of a crenarchaeon, Cenarchaeum symbiosum, suggested that the mesophilic Crenarchaeota were different from hyperthermophilic Crenarchaeota, and the former became the Thaumarchaeota, the third archaeal phylum (BrochierArmanet et al. 2008).

Archaea are found throughout the water column in the world's ocean from low to high latitudes. Generally, Thaumarchaeota appear to be the most abundant archaeal group in the ocean, and their relative abundance typically increases with depth (DeLong et 
al. 1999, Karner et al. 2001, Church et al. 2003). Previous studies have presented profiles of archaeal abundance in ocean regions including the North Pacific (DeLong et al. 1999, Karner et al. 2001), the Atlantic (Herndl et al. 2005, Teira et al. 2006, Schattenhofer et al. 2009), the North Sea (Herfort et al. 2007), the Southern Ocean near the Antarctic Peninsula (Church et al. 2003), and the western Arctic Ocean (Kirchman et al. 2007). Thaumarchaeal abundance also shows seasonal variability, and they are highly abundant in winter surface water near the Antarctic Peninsula (Church et al. 2003).

Information about archaeal distributions in the Pacific sector of the Arctic Ocean-composed of the Chukchi Sea, the Canada Basin, and the East Siberian Sea - is almost exclusively limited to the Canadian side. Studies to date have shown that Archaea make up a relatively low proportion of the total prokaryotes in surface waters of the Canadian Arctic and the Beaufort Sea (Wells \& Deming 2003, Garneau et al. 2006). Seasonal changes in archaeal abundance were demonstrated using denaturing gradient gel electrophoresis (DGGE) (Bano et al. 2004) and FISH with catalyzed reporter deposition (CARD-FISH) (Alonso-Sáez et al. 2008). These analyses showed a large proportional abundance of Archaea in winter decreasing to almost undetectable levels in summer in the surface layer in the Arctic Ocean. Kirchman et al. (2007) reported that thaumarchaeal relative abundance increased with depth from the Chukchi Sea to the Canada Basin in spring and summer. Furthermore, even though the Arctic Ocean is characterized by high river inflow, archaeal 16S rRNA gene libraries for the coastal Arctic Ocean differ from those in the rivers, indicating an active autochthonous community rather than one derived from river inflow, and Euryarchaeota predominate in the surface water of the coastal Beaufort Sea, where they are associated with particle-rich water (Galand et al. 2006, 2008).

To understand the distribution of Archaea in the Arctic Ocean, it is necessary to consider the Arctic water mass structure. From top to bottom, the watermass structure of the Pacific sector of the Arctic Ocean consists of Surface Mixed Layer Water (SMLW) (Shimada et al. 2001) at the surface, Pacific origin water, the Atlantic Layer (AL), Deep Water (DW), and Bottom Water (BW) (Jones et al. 1995, Carmack et al. 1997, Jones 2001). The cold and low salinity SMLW is typically found in the upper $50 \mathrm{~m}(28.0<$ salinity $<33.5$, temperature $<0^{\circ} \mathrm{C}$ ). Two halocline layers (HL) form in the Pacific sector of the Arctic Ocean: one is between SMLW and the Pacific inflow, and the other is between the Pacific and Atlantic inflows. In the present study, the upper and lower halocline layers through the Pacific inflow were regarded as a single HL (Jones 2001). The most prominent water-column feature of the Arctic Ocean is the warm AL at maximum depths ranging between 200 and $500 \mathrm{~m}$ in the Canada Basin $(34.5<$ salinity < 34.8 , temperature $\sim 0.5^{\circ} \mathrm{C}$ ). Below the AL is the DW between 1700 and $2500 \mathrm{~m}$; the deepest BW has a salinity of 35 and a temperature of $-0.53^{\circ} \mathrm{C}$ below $2500 \mathrm{~m}$.

To clearly characterize the distribution of Archaea in the Arctic Ocean, it would be useful to include information about Arctic Ocean water-mass structure. Our goal in the present study was to clarify geographic patterns of archaeal abundance and to determine which environmental factors affect this distribution. To this end, we determined the archaeal spatial distributions in different areas and water masses of the Pacific sector of the Arctic Ocean.

\section{MATERIALS AND METHODS}

\section{Sample collection}

Seawater samples were collected from a total of 16 stations during Cruise MR08-04 aboard the RV 'Mirai' of the Japan Agency for Marine-Earth Science and Technology (JAMSTEC) from 26 August to 9 October 2008 (Fig. 1). The samples were collected from 4 to 11 depths at each sampling station using a sampling rosette with 36 Niskin bottles (12 l each) and a conductivity-temperature-depth (CTD) system.

Seawater samples from Niskin bottles were analyzed on board for water temperature, salinity (AUTOSAL 8400B, Guildline Instruments), dissolved oxygen (Winkler method with automatic titration [titrator model DOT-01, Kimoto Electric]), nutrient concentrations (nitrate, nitrite, ammonium, phosphate, and silicate; TRACCS-800, BRAN+LUEBBE), and chlorophyll fluorescence (Chlorophyll Fluorometer, S/N 2936, Seapoint Sensors). Further details are available online at the website for RV 'Mirai' research cruise data for 2008 (www.godac.jamstec. go.jp/cruisedata/mirai/e/MR08-04.html).

\section{Prokaryotic abundance}

The abundance of marine planktonic prokaryotes was determined by CARD-FISH (Pernthaler et al. 2002a). The method used in the present study was 


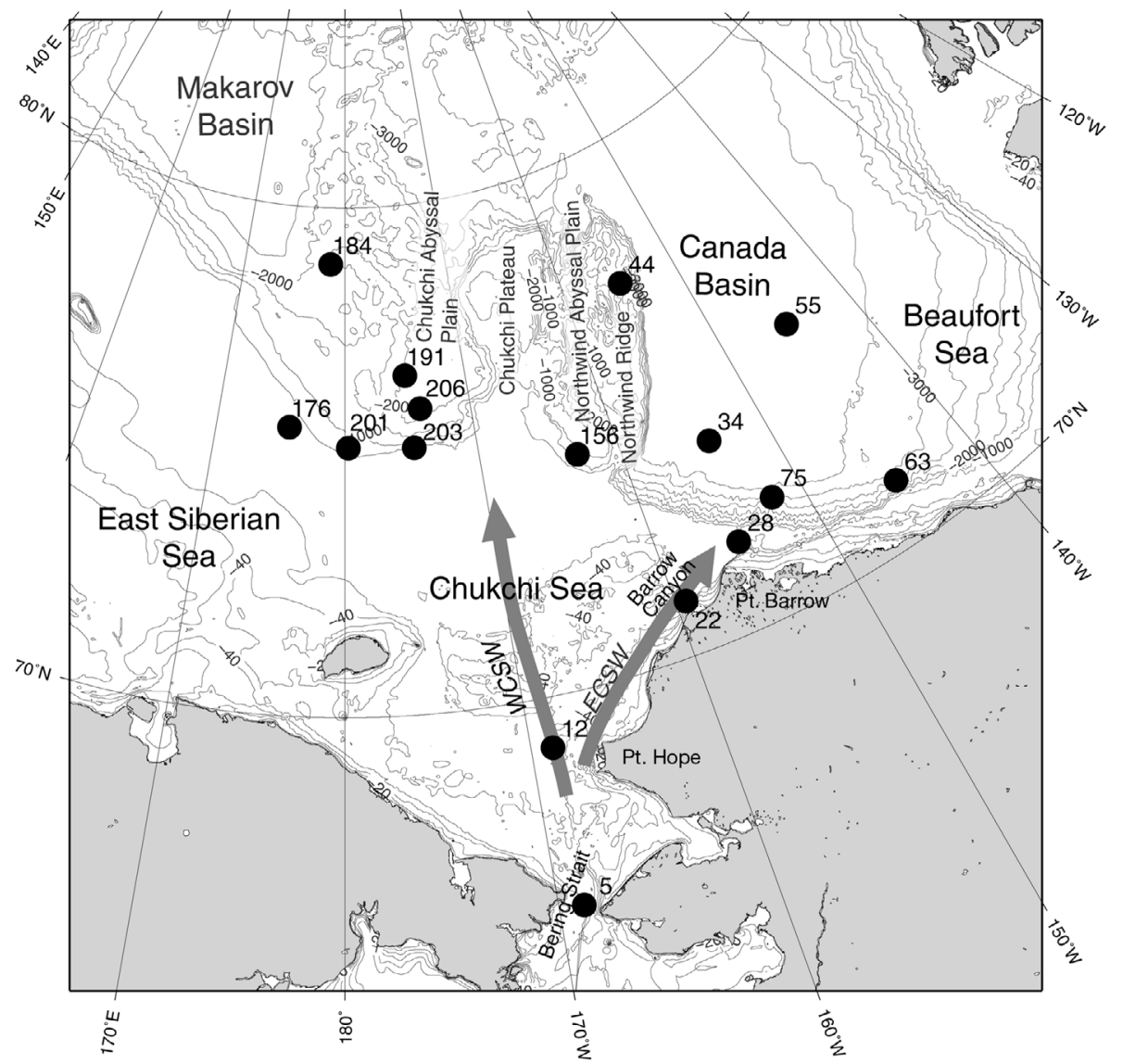

Fig. 1. Sampling stations (0) in the Arctic Ocean during RV 'Mirai' Cruise MR08-04. Station numbers are next to sampling stations. Bottom topography is from the International Bathymetric Chart of the Arctic Ocean (IBCAO) (Jakobsson et al. 2008). Grey arrows indicate water currents from the Pacific Ocean: West Chukchi Summer Water (WCSW) and East Chukchi Summer Water (ECSW) based primarily on the method of Teira et al. (2004). Seawater samples were fixed immediately after collection with particle-free formalin (final conc. $3 \%$ ), filtered on board through white polycarbonate membrane filters $(0.2 \mu \mathrm{m}$ pore size, $25 \mathrm{~mm}$ diameter; Millipore), and kept at $-80^{\circ} \mathrm{C}$ until the end of the cruise. The volume filtered varied from 10 to $100 \mathrm{ml}$, depending on the sampling depth. Filter samples were embedded in $0.1 \%$ agarose, dried at $37^{\circ} \mathrm{C}$, and then briefly dipped in $96 \%$ ethanol. Cells were permeabilized using either $0.2 \mu \mathrm{l} \mathrm{ml}^{-1}$ Proteinase K (Fluka) for Archaea or $10 \mathrm{mg} \mathrm{ml}^{-1}$ lysozyme (Sigma-Aldrich) for Bacteria at $37^{\circ} \mathrm{C}$ for $60 \mathrm{~min}$. The permeabilization buffer was $0.05 \mathrm{~mol} \mathrm{l}^{-1}$ ethylenediaminetetraacetic acid (EDTA) and $0.1 \mathrm{~mol} \mathrm{l}^{-1}$ Tris-HCl (pH 8.0). After permeabilization, the filters were washed with ultrapure water and placed in $0.01 \mathrm{~mol} \mathrm{l}^{-1} \mathrm{HCl}$ at room temperature for $20 \mathrm{~min}$. After soaking in $\mathrm{HCl}$, the filters were washed twice with ultrapure water, dipped briefly in $96 \%$ ethanol, and dried at room temperature. The filters were prepared by cutting them into smaller pieces, and then each filter piece was treated with a different probe: a probe for Thaumarchaeota, Euryarchaeota, Bacteria, or a negative control (Table 1). In the present study, the negative control accounted for $<1 \%$ of 4',6-diamidino-2-phenylindole (DAPI) counts, defined as the number of cells positively stained by DAPI. Filter pieces were incubated in a solution containing $15 \mu \mathrm{l}$ of the appropriate hybridization probe (stock solution: $50 \mathrm{ng} \mathrm{\mu l}^{-1}$ ) added

Table 1. Probes and hybridization conditions used for CARD-FISH

\begin{tabular}{|lllll|}
\hline Probe & Probe sequence $\left(5^{\prime}-3^{\prime}\right)$ & Target group & Formamide & Source \\
& & & 20 & Massana et al. (1997) \\
CREN554 & TTA GGC CCA ATA ATC MTC CT & Thaumarchaeota & 20 & Teira et al. (2004) \\
Eury806 & CAC AGC GTT TAC ACC TAG & Euryarchaeota & 55 & Amann et al. (1990) \\
EUB338 & GCT GCC TCC CGT AGG AGT & Bacteria & 55 & Wallner et al. (1993) \\
NON338 & ACT CCT ACG GGA GGC AGC & Negative control & & \\
\hline
\end{tabular}


to $300 \mu \mathrm{l}$ of hybridization buffer $\left(0.9 \mathrm{~mol} \mathrm{l}^{-1} \mathrm{NaCl}\right.$, $20 \mathrm{mmol} \mathrm{l}^{-1}$ Tris-HCl [pH 7.5], $10 \%$ [wt:vol] dextran sulfate, $0.02 \%$ [wt:vol] sodium dodecyl sulfate, and $1 \%$ blocking reagent) and the appropriate concentration of formamide (Table 1) (Teira et al. 2004) and incubated at $35^{\circ} \mathrm{C}$ for $12 \mathrm{~h}$. After hybridization, the filter pieces were transferred into $50 \mathrm{ml}$ of prewarmed washing buffer (5 mmol $\mathrm{l}^{-1}$ EDTA [pH 8.0], $20 \mathrm{mmol} \mathrm{l}^{-1}$ Tris-HCl [pH 7.4 to 7.6 ], $0.01 \%$ sodium dodecyl sulfate, and $\mathrm{NaCl}$ at a concentration appropriate to the amount of formamide used). The filter pieces were then placed in phosphate-buffered saline (PBS; $145 \mathrm{mmol} \mathrm{l}^{-1} \mathrm{NaCl}, 1.4 \mathrm{mmol} \mathrm{l}^{-1} \mathrm{NaH}_{2} \mathrm{PO}_{4}$, and $8 \mathrm{mmol} \mathrm{l}^{-1} \mathrm{Na}_{2} \mathrm{HPO}_{4}$ [pH 7.6]) amended with $0.05 \%$ Triton X-100 (ICN Biomedicals) (PBS-T mix) at room temperature for $15 \mathrm{~min}$. Signal amplification was performed in $498 \mu \mathrm{l}$ of amplification buffer (10\% [wt:vol] dextran sulfate, $2 \mathrm{~mol} \mathrm{l}^{-1} \mathrm{NaCl}, 0.1 \%$ [wt:vol] blocking reagent, and $0.0015 \% \mathrm{H}_{2} \mathrm{O}_{2}$ in PBS) and $5 \mu \mathrm{l}$ of tyramide-Alexa488 $\left(1 \mathrm{mg} \mathrm{ml}^{-1}\right)$ and incubated at $37^{\circ} \mathrm{C}$ for $45 \mathrm{~min}$. After amplification, the filters were washed in PBS-T mix at room temperature for $10 \mathrm{~min}$ and then rinsed in ultrapure water and $96 \%$ ethanol. The samples were then dried at room temperature and counterstained with DAPI. Cells were counted using a microscope with a mercury-vapor lamp (Olympus BX-50). For each group of planktonic prokaryotes, the number of cells counted was usually from 200 to 1100; this is within the range of reasonable counts suggested by Kirchman et al. (1982).

Generic Mapping Tools (Wessel \& Smith 1991, 1998) was used to display the sample data.

\section{Data analysis}

To investigate the relationships between prokaryotic distributions and ambient environmental conditions, we created a Pearson correlation (r) matrix for simple linear regression analyses. Redundant variables were eliminated by running a stepwise procedure with Akaike's information criterion (AIC). The abundance of each archaeal group was then modeled by multiple correlation analysis with environmental factors selected by the stepwise procedure.

Prokaryotic relative abundance data and data describing environmental conditions at all of our stations were used for canonical correspondence analysis (CCA) (Ter Braak 1986). CCA allows a visual interpretation of multiple habitat dimensions by plotting the abundance of each taxon along with a biplot of environmental variables in the ordination diagram formed by 2 canonical axes obtained by the environ- mental CCA. Based on the ranked scores from the CCA, water at each sampling depth at each station was placed into clusters by hierarchical cluster analysis and visualized on the CCA plot as groups of data points encircled by dashed lines. All calculations and simulations were performed using R v. 2.15.2 (http:// cran.md.tsukuba.ac.jp/) and SPSS v. 21 (IBM).

\section{RESULTS}

\section{Environmental parameters and water masses of the Arctic Ocean, Pacific sector}

We used data for typical geochemical parameters from Cruise MR08-04 and from previous studies to categorize the sea areas and water masses in the Pacific sector of the Arctic Ocean (Table 2). At Stn 5 in the Bering Strait, inorganic nutrient concentrations (nitrate, nitrite, ammonium, phosphate, and silicate) were higher than in other areas, and below the surface (from $8 \mathrm{~m}$ to the bottom), temperature and salinity were constant. Chukchi Sea Stn 12 was characterized by relatively saltier Western Chukchi Summer Water (WCSW) (Fig. 1); Stns 22 and 28 in the Barrow Canyon (BC) had water with different properties. Stns 34, 55, 63, and 75 exhibited an Arctic water-mass structure (Carmack et al. 1997, Jones 2001) consisting of low-salinity SMLW at the surface underlain by an $\mathrm{HL}$, a relatively warm $\mathrm{AL}$, then $\mathrm{DW}$, and $\mathrm{BW}$ at the bottom (Fig. 2). The vertical profiles and ranges of nutrient concentrations at the Northwind Ridge (Stns 44 and 156) were almost the same as in the Canada Basin. Stations along the East Siberian Sea side of the study area (Stns 176, 184, 201, 203, and 206) also had water-mass profiles that included SMLW, an $\mathrm{HL}, \mathrm{AL}$, and DW. Dissolved oxygen concentrations decreased with depth overall, and there was usually an oxygen minimum layer between 100 and $300 \mathrm{~m}$ depth in the Pacific sector of the Arctic Ocean.

\section{Archaeal and bacterial distributions}

CARD-FISH detected approximately 80 to $100 \%$ of the prokaryotes on each filter sample. Generally, the relative abundance of each prokaryotic group as a proportion of the total number of prokaryotes, defined as the number of DAPI-positive cells, were, in decreasing order, Bacteria, Thaumarchaeota, and Euryarchaeota. We used this absolute cell abundance data to characterize the vertical and horizontal distributions of planktonic Archaea. 


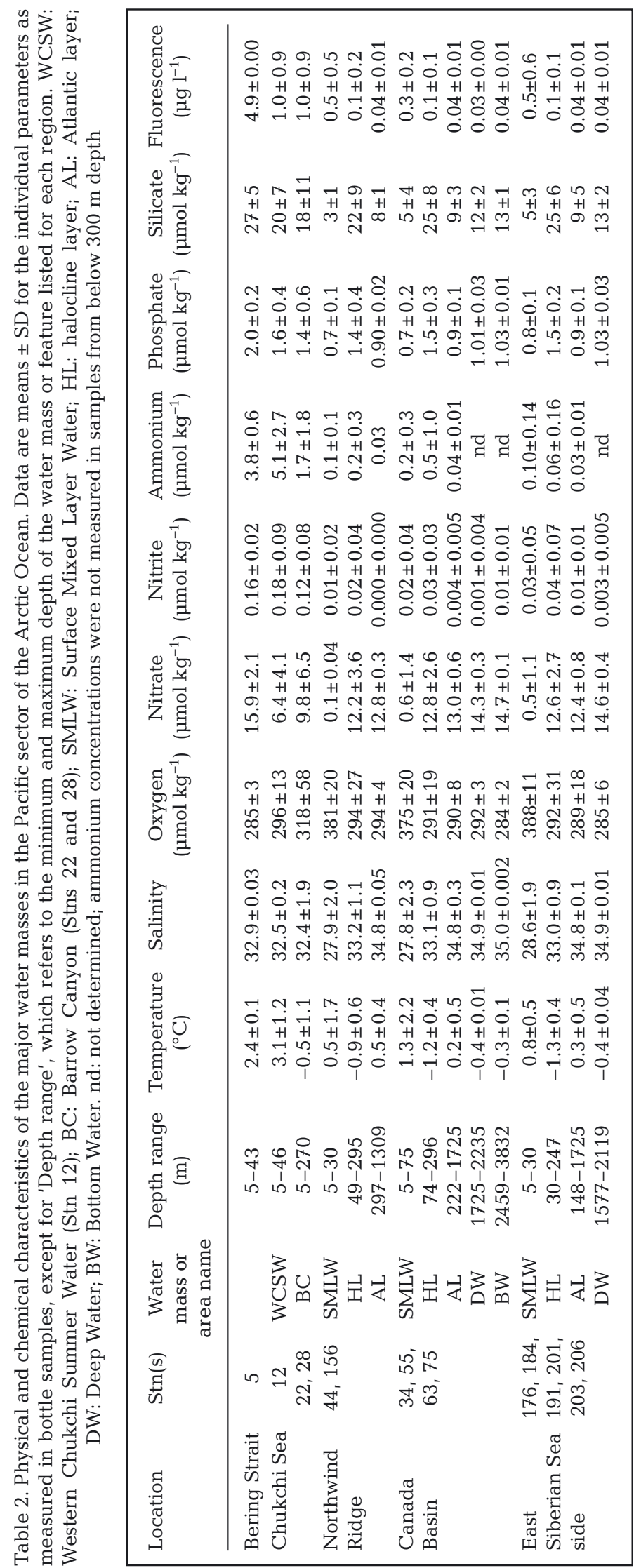

Archaeal and bacterial abundances were almost constant with depth in the Bering Strait (Stn 5), similar to the profiles of hydrographic parameters. Bacterial abundance was 5.4 to $8.1 \times$ $10^{5}$ cells $\mathrm{ml}^{-1}$ and averaged $92 \%$ of total DAPI counts, in contrast to the low percentage abundance of Archaea (Table 3).

In the Chukchi Sea, abundances of the respective prokaryotic groups at Stn 22 in the Barrow Canyon were almost the same as those in the Bering Strait, but at Stn 12, they were significantly higher than at Stn 22 (Student's $t$-test; $\mathrm{p}<$ 0.001 for Bacteria, Euryarchaeota, and total DAPI counts; $\mathrm{p}<0.01$ for Thaumarchaeota). At Stns 12, 22 , and 28 , the thaumarchaeal relative abundance was as low (average $2 \%$ ) as in the Bering Strait. Notably, at Stn 12, Euryarchaeota had both a high cell density and a high percentage abundance $(>10 \%)$. This high proportion of Euryarchaeota was not observed in the other areas (Fig. 2).

At Stns 34, 55, 63, and 75 in the Canada Basin, the average total prokaryotic abundance was $3.5 \times 10^{5}$ cells ml $^{-1}$ in the SMLW and decreased with depth to $1.6 \times 10^{4}$ cells ml $^{-1}$ in BW. Bacterial abundance profiles paralleled those of total DAPI counts, and the bacterial relative abundance was higher than that of Archaea (Fig. 2, Table 3). Overall, at these stations, thaumarchaeal abundance decreased with depth but not as rapidly as total DAPI counts, so the relative abundance of Thaumarchaeota increased with depth from 3\% in the SMLW to $15 \%$ in BW (Table 3). In addition, in the surface layer at Stns 55 and 75, thaumarchaeal abundances were substantially lower than those of Euryarchaeota. This trend was also evident in profiles from the base of the Northwind Ridge (Stn 156).

On the East Siberian Sea side, archaeal abundance increased with depth at some stations. At Stn 176 in particular, Thaumarchaeota increased from $7.4 \times 10^{3}$ cells ml ${ }^{-1}$ at the surface to $3.7 \times$ $10^{4}$ cells ml-1 at the bottom, and Euryarchaeota increased from $5.3 \times 10^{3}$ cells ml ${ }^{-1}$ at the surface to $8.7 \times 10^{3}$ cells ml $^{-1}$ at the bottom (Fig. 2). This trend was also found near Stn 176 during an expedition in 2010 (MR10-05; data not shown). Thaumarchaeal abundance at $200 \mathrm{~m}$ at Stn 176 accounted for $35 \%$ of total DAPI counts, the maximum thaumarchaeal relative abundance in the present study (Fig. 2). In contrast, the relative abundance of Euryarchaeota in this area was low $(<10 \%)$ in SMLW, HL, AL, and DW (Table 3). 

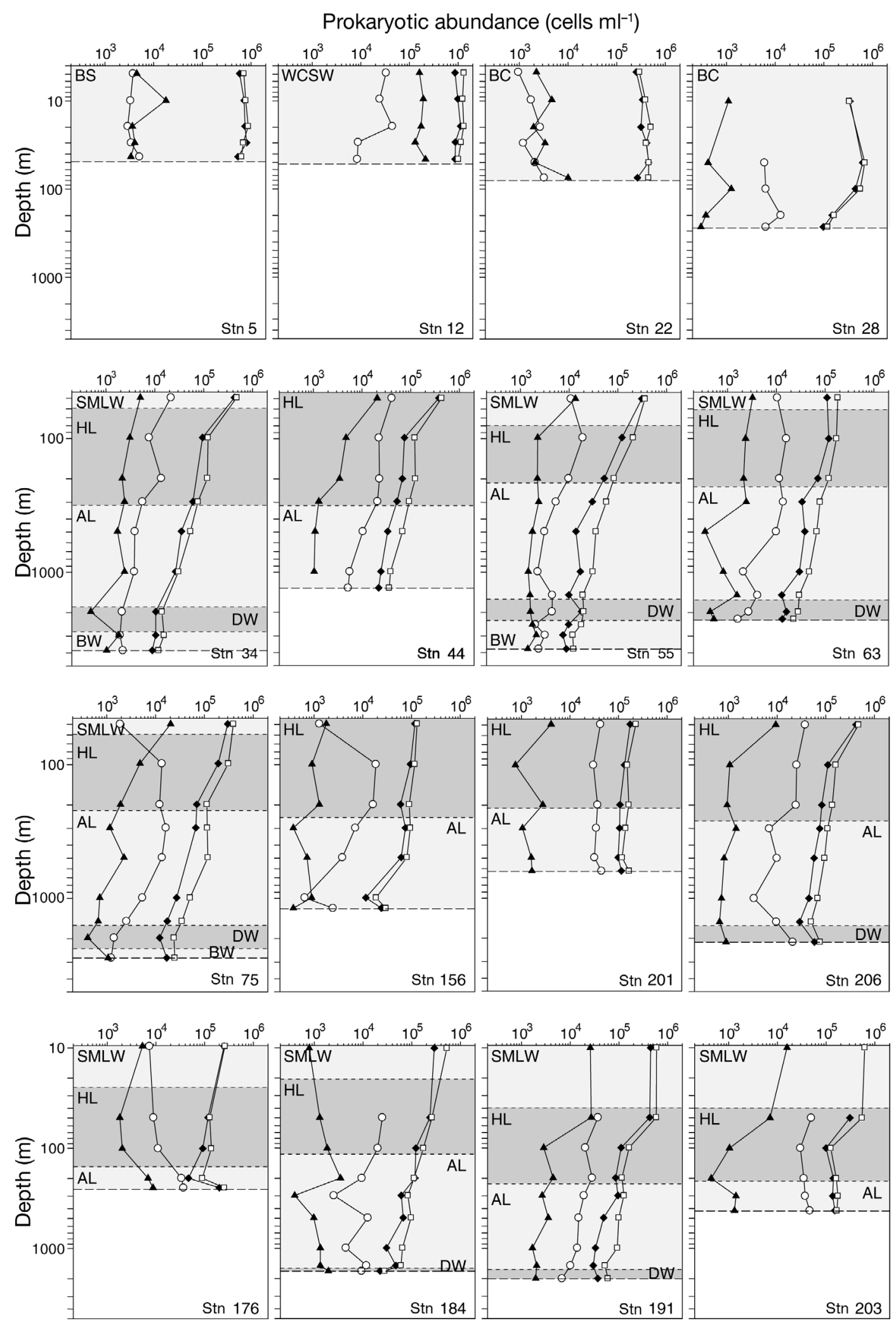

Fig. 2. Vertical profiles of prokaryotic abundance. O: Thaumarchaeota; $\mathbf{\Delta}$ : Euryarchaeota; $\$$ : Bacteria; $\square$ : total prokaryotes. Note that the axes use logarithmic scales, and data for Stns 5, 12, 22, and 28 cover a different depth range than other stations. Dashed horizontal lines indicate bottom depth. Shading in panels indicates water masses: BS: Bering Strait; WCSW: Western Chukchi Summer Water; BC: Barrow Canyon; SMLW: Surface Mixed Layer Water; HL: halocline layer; AL: Atlantic layer; DW: 
Table 3. Relative and total abundances of prokaryotes in water masses of the Arctic Ocean, Pacific sector. Relative abundances are expressed as percentages of the total counts of DAPI-stained cells. WCSW: Western Chukchi Summer Water; BC: Barrow

Canyon; SMLW: Surface Mixed Layer Water; HL: halocline layer; AL: Atlantic layer; DW: Deep Water; BW: Bottom Water

\begin{tabular}{|c|c|c|c|c|c|c|c|c|c|c|c|c|c|c|}
\hline \multirow[t]{2}{*}{ Location } & \multirow[t]{2}{*}{$\operatorname{Stn}(\mathrm{s})$} & \multirow{2}{*}{$\begin{array}{c}\text { Water } \\
\text { mass or } \\
\text { area name }\end{array}$} & \multicolumn{3}{|c|}{ Thaumarchaeota } & \multicolumn{3}{|c|}{$\begin{array}{l}\text { Proportion (\%) } \\
\text { Euryarchaeota }\end{array}$} & \multicolumn{3}{|c|}{ Bacteria } & \multicolumn{3}{|c|}{$\begin{array}{l}\text { Total cell abundance } \\
\qquad\left(\times 10^{4} \text { cells ml }^{-1}\right)\end{array}$} \\
\hline & & & Mean & $\mathrm{SD}$ & $\mathrm{n}$ & Mean & $\mathrm{SD}$ & $\mathrm{n}$ & Mean & $\mathrm{SD}$ & $\mathrm{n}$ & Mean & $\mathrm{SD}$ & $\mathrm{n}$ \\
\hline Bering Strait & 5 & & 0.5 & 0.2 & 5 & 0.9 & 0.8 & 5 & 92 & 14 & 5 & 74 & 9 & 5 \\
\hline Chukchi Sea & $\begin{array}{c}12 \\
22,28\end{array}$ & $\begin{array}{c}\text { WCSW } \\
\text { BC }\end{array}$ & $\begin{array}{l}2 \\
2\end{array}$ & $\begin{array}{l}1 \\
3\end{array}$ & $\begin{array}{c}5 \\
11\end{array}$ & $\begin{array}{l}15 \\
0.6\end{array}$ & $\begin{array}{c}4 \\
0.6\end{array}$ & $\begin{array}{c}5 \\
11\end{array}$ & $\begin{array}{l}79 \\
86\end{array}$ & $\begin{array}{c}8 \\
15\end{array}$ & $\begin{array}{c}5 \\
11\end{array}$ & $\begin{array}{c}120 \\
40\end{array}$ & $\begin{array}{l}13 \\
17\end{array}$ & $\begin{array}{c}5 \\
11\end{array}$ \\
\hline $\begin{array}{l}\text { Northwind } \\
\text { Ridge }\end{array}$ & 44,156 & $\begin{array}{l}\mathrm{HL} \\
\mathrm{AL}\end{array}$ & $\begin{array}{c}15 \\
9\end{array}$ & $\begin{array}{l}7 \\
5\end{array}$ & $\begin{array}{l}7 \\
7\end{array}$ & $\begin{array}{l}2 \\
2\end{array}$ & $\begin{array}{l}2 \\
2\end{array}$ & $\begin{array}{l}7 \\
7\end{array}$ & $\begin{array}{l}71 \\
66\end{array}$ & $\begin{array}{l}15 \\
11\end{array}$ & $\begin{array}{l}7 \\
7\end{array}$ & $\begin{array}{c}16 \\
5\end{array}$ & $\begin{array}{c}12 \\
3\end{array}$ & $\begin{array}{l}7 \\
7\end{array}$ \\
\hline Canada Basin & $\begin{array}{l}34,55 \\
63,75\end{array}$ & $\begin{array}{c}\text { SMLW } \\
\text { HL } \\
\text { AL } \\
\text { DW } \\
\text { BW }\end{array}$ & $\begin{array}{c}3 \\
9 \\
12 \\
13 \\
15\end{array}$ & $\begin{array}{l}2 \\
2 \\
5 \\
8 \\
7\end{array}$ & $\begin{array}{c}4 \\
9 \\
14 \\
5 \\
6\end{array}$ & $\begin{array}{c}3 \\
2 \\
3 \\
3 \\
11\end{array}$ & $\begin{array}{l}2 \\
1 \\
2 \\
2 \\
5\end{array}$ & $\begin{array}{c}4 \\
9 \\
14 \\
5 \\
6\end{array}$ & $\begin{array}{l}78 \\
65 \\
56 \\
66 \\
67\end{array}$ & $\begin{array}{c}13 \\
10 \\
12 \\
15 \\
8\end{array}$ & $\begin{array}{c}4 \\
8 \\
13 \\
5 \\
6\end{array}$ & $\begin{array}{c}35 \\
15 \\
5 \\
2 \\
2\end{array}$ & $\begin{array}{c}12 \\
7 \\
3 \\
1 \\
0.5\end{array}$ & $\begin{array}{c}4 \\
9 \\
14 \\
5 \\
6\end{array}$ \\
\hline $\begin{array}{l}\text { East Siberian } \\
\text { Sea side }\end{array}$ & $\begin{array}{l}176,184 \\
191,201 \\
203,206\end{array}$ & $\begin{array}{c}\text { SMLW } \\
\text { HL } \\
\text { AL } \\
\text { DW }\end{array}$ & $\begin{array}{c}5 \\
15 \\
17 \\
24\end{array}$ & $\begin{array}{c}- \\
7 \\
9 \\
11\end{array}$ & $\begin{array}{c}1 \\
16 \\
20 \\
3\end{array}$ & $\begin{array}{l}3 \\
2 \\
2 \\
4\end{array}$ & $\begin{array}{l}2 \\
1 \\
2 \\
3\end{array}$ & $\begin{array}{c}4 \\
16 \\
20 \\
3\end{array}$ & $\begin{array}{l}77 \\
77 \\
67 \\
73\end{array}$ & $\begin{array}{c}19 \\
9 \\
14 \\
9\end{array}$ & $\begin{array}{c}3 \\
16 \\
20 \\
3\end{array}$ & $\begin{array}{c}50 \\
23 \\
11 \\
5\end{array}$ & $\begin{array}{c}16 \\
16 \\
5 \\
2\end{array}$ & $\begin{array}{c}4 \\
16 \\
20 \\
3\end{array}$ \\
\hline
\end{tabular}

\section{Correlation between Archaeal abundance and environmental factors}

Correlation analysis did not reveal any single specific geochemical factor associated with thaumarchaeal relative abundance (Table 4). A stepwise procedure was then used for multiple linear regression analysis to eliminate redundant environmental variables and to rank relevant environmental factors. According to the environmental factors selected by AIC analysis, thaumarchaeal relative abundance can be explained as follows:
Thaumarchaeal relative abundance $=$

$$
-0.43\left(\mathrm{NH}_{4}\right)-0.42(\mathrm{Oxy})-0.19 \text { (Fluor) }
$$

where $\mathrm{NH}_{4}$ is the ammonium concentration, $\mathrm{Oxy}$ is the dissolved oxygen concentration, and Fluor is the chlorophyll fluorescence (for this relation, $\mathrm{n}=111$, $\left.\mathrm{R}^{2}=0.59, F=31.2, \mathrm{p}<0.001\right)$. Each coefficient is a standard partial regression coefficient $(\beta)$ used to compare the contribution of each independent variable.

Multiple linear regression analysis showed that $\mathrm{NH}_{4}$ was the environmental factor with the strongest correlation to thaumarchaeal relative abundance;

Table 4. Correlation (r) matrix between prokaryotic relative abundances and environmental variables. Thaum: Thaumarchaeota; Eury: Euryarchaeota; Bact: Bacteria. Correlation is based on relative abundance as a proportion of total prokaryotes (4',6-diamidino-2-phenylindole [DAPI]-positive cells). Temp: temperature; Sal: salinity; Oxy: dissolved oxygen; $\mathrm{NO}_{3}$ : nitrate; $\mathrm{NO}_{2}$ : nitrite; $\mathrm{NH}_{4}$, ammonium; $\mathrm{PO}_{4}$ : phosphate; $\mathrm{SiO}_{2}$ : silicate; Fluor: chlorophyll fluorescence. $\mathrm{n}=111$ except for ammonium $(n=69)$, which was only determined in samples from the upper $300 \mathrm{~m}$. Significant correlations $(\mathrm{p}<0.01)$ in bold

\begin{tabular}{|c|c|c|c|c|c|c|c|c|c|c|c|c|}
\hline & Thaum & Eury & Bact & Temp & Sal & Oxy & $\mathrm{NO}_{3}$ & $\mathrm{NO}_{2}$ & $\mathrm{NH}_{4}$ & $\mathrm{PO}_{4}$ & $\mathrm{SiO}_{2}$ & Fluor \\
\hline Thaum & 1 & & & & & & & & & & & \\
\hline Eury & - & 1 & & & & & & & & & & \\
\hline Bact & -0.24 & - & 1 & & & & & & & & & \\
\hline Temp & -0.23 & 0.33 & - & 1 & & & & & & & & \\
\hline Sal & 0.47 & - & -0.45 & - & 1 & & & & & & & \\
\hline Oxy & -0.37 & - & 0.23 & - & -0.74 & 1 & & & & & & \\
\hline $\mathrm{NO}_{3}$ & 0.35 & -0.11 & -0.22 & -0.16 & 0.74 & -0.87 & 1 & & & & & \\
\hline $\mathrm{NO}_{2}$ & -0.47 & 0.10 & 0.49 & 0.12 & -0.46 & 0.14 & -0.19 & 1 & & & & \\
\hline $\mathrm{NH}_{4}$ & -0.53 & 0.49 & 0.32 & 0.45 & - & -0.21 & 0.17 & 0.68 & 1 & & & \\
\hline $\mathrm{PO}_{4}$ & -0.27 & - & 0.33 & -0.16 & -0.31 & -0.29 & 0.33 & 0.61 & 0.64 & 1 & & \\
\hline $\mathrm{SiO}_{2}$ & - & - & 0.27 & -0.22 & -0.30 & -0.33 & 0.34 & 0.33 & 0.36 & 0.87 & 1 & \\
\hline Fluor & -0.46 & - & 0.45 & 0.41 & -0.29 & - & - & 0.53 & 0.54 & 0.51 & 0.30 & 1 \\
\hline
\end{tabular}




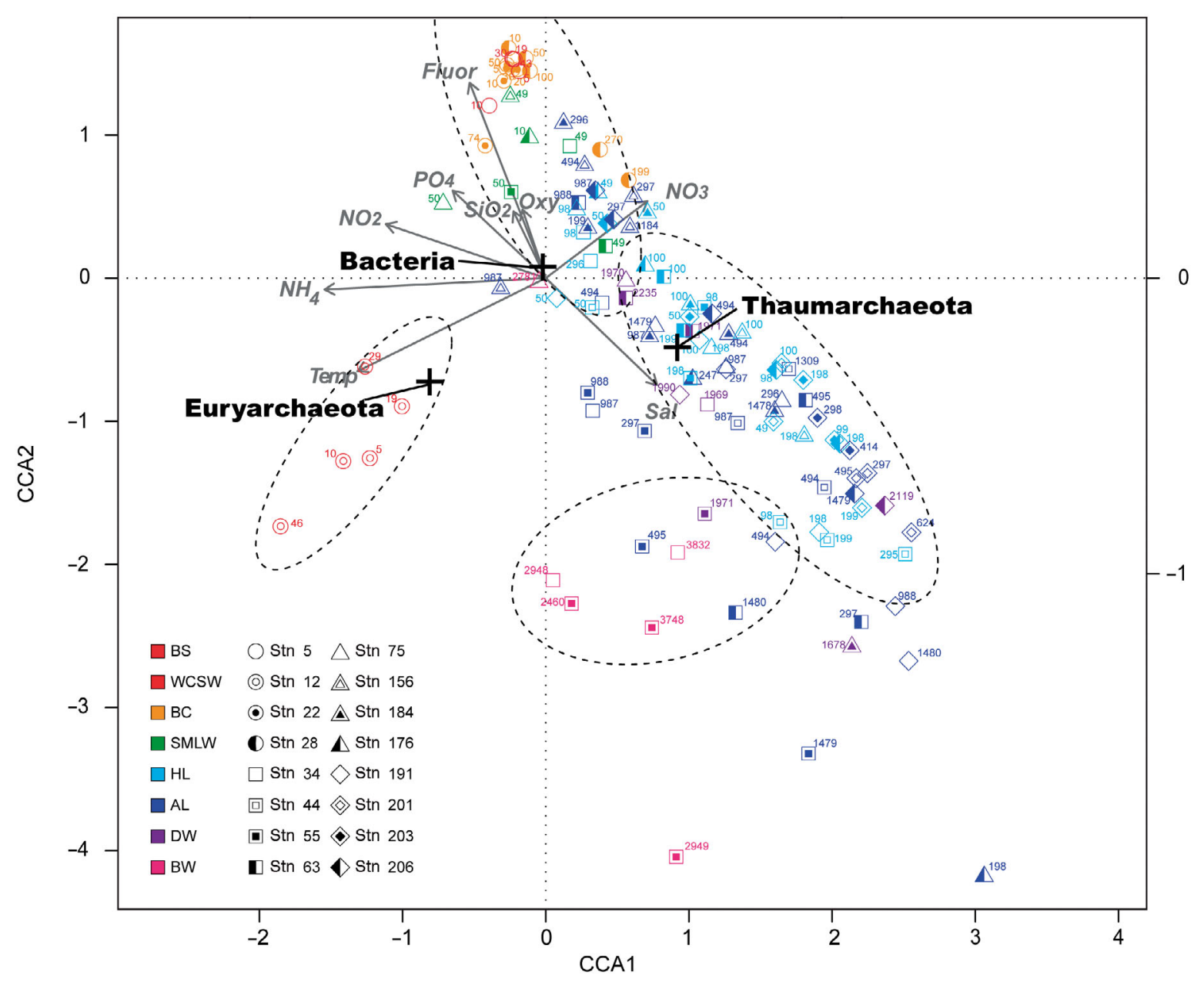

Fig. 3. Canonical correspondence analysis (CCA) of environmental variables and archaeal distributions in the Pacific sector of the Arctic Ocean. Environmental conditions are presented as a biplot associated with the right and upper axes. Grey arrows indicate increasing values for environmental parameters. Each station is indicated by a different symbol. Dashed lines encircle each cluster. Numbers near symbols indicate sample depth $(\mathrm{m})$. Different colors represent different water masses as indicated in the figure key: BS: Bering Strait; WCSW: Western Chukchi Summer Water; BC: Barrow Canyon; SMLW: Surface Mixed Layer Water; HL: halocline layer; AL: Atlantic layer; DW: Deep Water; BW: Bottom Water

Oxy and Fluor were also contributing factors. The thaumarchaeal relative abundance was negatively correlated with $\mathrm{NH}_{4}, \mathrm{Oxy}$ and Fluor, in order of decreasing importance. For the analysis, we set $\mathrm{NH}_{4}$

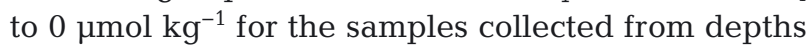
below $300 \mathrm{~m}$; these concentrations were not measured because empirical predictions said that the concentrations were very low. We later confirmed that Eq. (1) is not changed by using only data from samples collected above $300 \mathrm{~m}$ depth $(\mathrm{n}=69)$, for which measured $\mathrm{NH}_{4}$ concentrations are available.

Simple linear correlation analysis showed high positive correlations between the relative abundance of Euryarchaeota and ammonium concentrations $(\mathrm{r}=$ $0.49, \mathrm{p}<0.001)$ and temperature $(\mathrm{r}=0.33, \mathrm{p}<0.001)$ (Table 4).

\section{Canonical correspondence analysis}

The CCA plot of Thaumarchaeota, Euryarchaeota, and individual sites shows well-dispersed distributions of species and environmental variables (Fig. 3). The first 2 partial CCA axes accounted for 51.3 and $26.9 \%$, respectively, of the total variance; the axes combined accounted for $\sim 78.2 \%$.

The Thaumarchaeota were found in waters with higher salinity and lower phosphate, nitrite, and ammonium concentrations. In particular, samples from the AL at Stn 176 (198 m) and from the BW at Stn $55(2949 \mathrm{~m})$ are representative sites for the occurrence of Thaumarchaeota according to CCA (Fig. 3). Similarly, water from the HL, AL, and DW at most stations were included in a cluster of characteristic 
sites with notable thaumarchaeal cell abundance, and another cluster included the BW from Stns 34 and 55 (Fig. 3). There were a number of stations and depths, especially in the Canada Basin, that were not grouped together by the CCA and were instead separated depending on environmental conditions. For example, the fact that the CCA placed the SMLW from Stn 55 near water from the Bering Strait and Barrow Canyon with high chlorophyll fluorescence and relatively far from Stn 55 DW with high salinity reflects continuous ecological gradients. These results suggest that Thaumarchaeota are found in areas of higher salinity and also in the HL, where nutrient concentrations change drastically in the Arctic Ocean.

The CCA found that Euryarchaeota were characteristic of WCSW (Stn 12), with high temperatures and ammonium concentrations, in agreement with the results from the correlation analysis (Table 4). The WCSW at Stn 12 had notably higher temperatures and ammonium concentrations than other water masses (Table 2).

\section{DISCUSSION}

The CCA visualization shows the distributions of Thaumarchaeota and Euryarchaeota to be essentially reflective of the Arctic water-mass structure. The Thaumarchaeota in particular appeared in characteristic water masses such as the HL, AL, and DW. Although the HL and AL were different hydrographically - all geochemical factors except dissolved oxygen and nitrate concentrations were significantly different between the AL and HL (Student's $t$-test; $\mathrm{p}<$ 0.05 for ammonium and $\mathrm{p}<0.001$ for other factors) Thaumarchaeota were frequently found in these different water masses. This suggests that Thaumarchaeota can survive well in the range of environmental conditions observed through the $\mathrm{HL}$ and $\mathrm{AL}$ (water temperature from -1.7 to $0.1^{\circ} \mathrm{C}$, salinity from 30.9 to 34.9). In comparing geochemical factors between waters with higher thaumarchaeal abundance (HL, AL, and DW) and those with lower abundance (BS, WCSW, BC, and SMLW), variables of salinity were significantly different (Student's $t$-test; $p<0.001)$. This result suggests that salinity variations influence the distribution of Thaumarchaeota in the Arctic Ocean, where lower-salinity water (approximately $<30 \mathrm{psu}$ ) is found in the summer as a result of melting ice and high river inflow. In the meso- and bathypelagic waters of the North Atlantic, where salinities ranged from 34.8 to $\sim 35.0$, Teira et al. (2006) reported a negative correlation between the relative abundance of Thaumarchaeota and salinity. It is possible, therefore, that under such a narrow salinity range, the thaumarchaeal relative abundance was negatively correlated with salinity, whereas there was a positive correlation under the wider salinity range from 23.9 to 35.0 in the Arctic Ocean.

The correlation analysis between archaeal abundance and geochemical factors and the CCA suggest that Thaumarchaeota would be found in waters with lower dissolved oxygen and depleted ammonium (Fig. 3). Kirchman et al. (2007) reported a positive correlation between ammonium concentration and the relative abundance of Thaumarchaeota in the Chukchi Sea and the Canada Basin. In contrast, in our study, neither the absolute abundance nor the relative abundance of Thaumarchaeota was positively correlated with ammonium concentration. For example, there was a high concentration of ammonium $\left(3.0 \mu \mathrm{mol} \mathrm{\textrm {kg } ^ { - 1 } )}\right.$ at $98 \mathrm{~m}$ depth at Stn 75 , but Thaumarchaeota were not abundant. Therefore, we suggest that in the Pacific sector of the Arctic Ocean, higher ammonium concentrations do not necessarily coincide with higher thaumarchaeal abundances. Any ammonium present would be rapidly taken up by a segment of the Thaumarchaeota or by other prokaryotes, the result being that we found a negative correlation between thaumarchaeal abundance and ammonium concentrations.

There is strong evidence for the existence of autotrophic ammonium-oxidizing Thaumarchaeota (Könneke et al. 2005). Christman et al. (2011) suggested that a large portion of the Thaumarchaeota in the coastal Arctic Ocean are ammonia oxidizers based on the results of a study using qPCR with archaeal ammonia monooxygenase subunit A (amoA) and thaumarchaeal 16S rRNA gene copies. In the present study, thaumarchaeal relative abundance was negatively correlated not only with ammonium concentrations but also with nitrite concentrations, whereas it was positively correlated with nitrate concentrations. If most Thaumarchaeota could oxidize ammonium, and there is another pathway converting nitrite to nitrate in the water column, our results could be explained; a high relative abundance of Thaumarchaeota would result in water with depleted ammonium and high nitrate concentrations. Moreover, if this explanation were valid, this autotrophic process would be widely occurring in the $\mathrm{HL}, \mathrm{AL}$, and DW in the Pacific sector of the Arctic Ocean.

Additionally, to date, there have been no studies directly comparing the geochemical characteristics of BW with surface or mesopelagic waters in the Arctic 
Ocean. Therefore, our results from CCA showing BW in a different cluster from other water masses indicate that CCA based on not only geochemical properties but also prokaryotic abundance is useful for understanding the deep Arctic Ocean water mass.

The thaumarchaeal fraction was very abundant near the bottom on the East Siberian Sea side of the Arctic Ocean (Table 3), particularly at Stns 176, 201, and 206 (Fig. 2). This tendency could also be seen along the Northwind Ridge at Stns 44 and 156 (Fig. 2). At the same stations, bacterial abundance also increased near the bottom. In comparing the environmental variables in the bottom and second from the bottom water samples from the Canada Basin, the Northwind Ridge, and the stations on the East Siberian Sea side, we found that silicate concentrations were significantly higher near the bottom of the sea (Student's $t$-test; $\mathrm{n}=12, \mathrm{p}<0.05$ ) (Table 5). In particular, at the Northwind Ridge and East Siberian Sea side stations, not only silicate but also phosphate and nitrate concentrations were much higher near the bottom (Student's $t$-test; $\mathrm{n}=7, \mathrm{p}<0.01$ for silicate, $\mathrm{p}<0.05$ for phosphate and nitrate). It seems that the proportionally more abundant thaumarchaeal and bacterial fractions in the bottom samples are related to higher concentration of nutrients, such as phosphate and nitrate.

Nishino et al. (2008) compared the west and east sides of the Pacific sector of the Arctic Ocean and found higher concentrations of chl $a$ and silicate in the surface waters on the East Siberian Sea side. This higher primary production near the surface would ultimately contribute to the composition of the water near the bottom on the East Siberian Sea side and along the Northwind Ridge. A comparison of our results from the same water masses on the Canadian and East Siberian Sea sides shows that the East Siberian Sea side had higher prokaryotic and bacterial abundance and higher relative thaumarchaeal abundance in the AL and DW (Table 3). Therefore, we suggest that the East Siberian Sea side provides more assimilative substrates for Thaumarchaeota and bacteria than the Canadian side.

Previous studies showed that Euryarchaeota were abundant in ocean surface layers of the Pacific and Arctic oceans (Pernthaler et al. 2002b, DeLong et al. 2006, Frigaard et al. 2006, Galand et al. 2009). We found that the Euryarchaeota were abundant in the shallow waters (BS, WCSW, BC, and SMLW; Table 3, Fig. 3), with a positive correlation with higher ammonium concentrations and temperatures. The abundance of Euryarchaeota at Stn $12\left(>10^{5} \mathrm{cells} \mathrm{ml}^{-1}\right)$ was significantly higher than at the other stations (1-way ANOVA, $\mathrm{p}<0.001)$. When Stn 12 data were omitted from the analysis, there was no significant difference among euryarchaeal abundance at all of the other stations $(p>0.05)$. These results suggest that there is a higher proportion of Euryarchaeota in the Chukchi Sea than in other areas of the Pacific sector of the Arctic Ocean or that this station is a 'hot spot' for Euryarchaeota.

\section{CONCLUSIONS}

In the present study, we characterized the archaeal distribution in the Pacific sector of the Arctic Ocean. Archaeal distribution was typically reflective of Arctic water-mass structure. The presence of Thaumarchaeota was negatively correlated with levels of ammonium, dissolved oxygen, and chlorophyll fluorescence. Also, Thaumarchaeota appeared in characteristic water masses, clustering with the $\mathrm{HL}, \mathrm{AL}$, and DW in the CCA visualization, a reflection primarily of salinity conditions. These results suggest that the water masses in the $\mathrm{HL}, \mathrm{AL}$, and DW, characterized by low ammonium, dissolved oxygen, and chlorophyll fluorescence and high salinity, influence the distribution of Thaumarchaeota in the Arctic Ocean, Pacific sector. In contrast, the Euryarchaeota ap-

Table 5. Environmental variables in the bottom (B) and second from the bottom (A) water samples in the Canada Basin, the Northwind Ridge, and the East Siberian Sea side. Data are means \pm SD for the individual parameters as measured in bottle samples, except for 'Depth range', which refers to the minimum and maximum depth of samples. CB: Canada Basin (Stns 34, 55, 63, and 75); NR: Northwind Ridge (Stns 44 and 156); ES: East Siberian Sea side (Stns 176, 184, 191, 201, 203, and 206)

\begin{tabular}{|c|c|c|c|c|c|c|c|c|c|}
\hline Location & Sample & $\begin{array}{l}\text { Depth } \\
\text { range (m) }\end{array}$ & $\begin{array}{c}\text { Temperature } \\
\left({ }^{\circ} \mathrm{C}\right)\end{array}$ & Salinity & $\begin{array}{c}\text { Oxygen } \\
\left.(\mu \mathrm{mol} \mathrm{kg})^{-1}\right)\end{array}$ & $\begin{array}{c}\text { Nitrate } \\
\left.(\mu \mathrm{mol} \mathrm{kg})^{-1}\right)\end{array}$ & $\begin{array}{c}\text { Nitrite } \\
\left(\mu \mathrm{mol} \mathrm{kg}{ }^{-1}\right)\end{array}$ & $\begin{array}{l}\text { Phosphate } \\
\left.(\mu \mathrm{mol} \mathrm{kg})^{-1}\right)\end{array}$ & $\begin{array}{c}\text { Silicate } \\
\left(\mu \mathrm{mol} \mathrm{kg}{ }^{-1}\right)\end{array}$ \\
\hline $\begin{array}{l}\mathrm{CB} \\
(\mathrm{n}=4)\end{array}$ & $\begin{array}{l}\text { A } \\
\text { B }\end{array}$ & $\begin{array}{l}1969-2949 \\
2235-3832\end{array}$ & $\begin{array}{l}-0.37 \pm 0.04 \\
-0.31 \pm 0.07\end{array}$ & $\begin{array}{l}34.9 \pm 0.0 \\
35.0 \pm 0.0\end{array}$ & $\begin{array}{l}286.1 \pm 3.0 \\
282.9 \pm 1.6\end{array}$ & $\begin{array}{l}14.6 \pm 0.1 \\
14.7 \pm 0.1\end{array}$ & $\begin{array}{l}0.00 \pm 0.01 \\
0.01 \pm 0.01\end{array}$ & $\begin{array}{l}1.03 \pm 0.02 \\
1.04 \pm 0.01\end{array}$ & $\begin{array}{l}12.8 \pm 0.9 \\
14.0 \pm 0.8\end{array}$ \\
\hline $\begin{array}{l}\text { NR and ES } \\
(n=8)\end{array}$ & $\begin{array}{l}\mathrm{A} \\
\mathrm{B}\end{array}$ & $\begin{array}{l}198-1480 \\
247-2119\end{array}$ & $\begin{array}{r}0.00 \pm 0.44 \\
-0.02 \pm 0.43\end{array}$ & $\begin{array}{l}34.8 \pm 0.1 \\
34.9 \pm 0.1\end{array}$ & $\begin{array}{l}292.1 \pm 12.6 \\
284.0 \pm 11.0\end{array}$ & $\begin{array}{l}12.9 \pm 0.4 \\
13.8 \pm 1.0\end{array}$ & $\begin{array}{l}0.01 \pm 0.01 \\
0.01 \pm 0.02\end{array}$ & $\begin{array}{l}0.92 \pm 0.03 \\
0.98 \pm 0.07\end{array}$ & $\begin{array}{r}8.9 \pm 2.0 \\
12.2 \pm 2.6\end{array}$ \\
\hline
\end{tabular}


peared only locally abundant and were associated with increased water temperatures in nutrient-rich water in the Chukchi Sea. Near the seafloor along the East Siberian Sea side and the Northwind Ridge, the proportional abundances of Thaumarchaeota and Bacteria were higher, apparently related to higher nutrient levels and the ability of these groups to carry out heterotrophic production in association with the higher surface primary production in this region compared to the Canadian side. These results expand our understanding of the distribution of Archaea in the Arctic Ocean and provide important basic data related to marine geochemical cycling through planktonic prokaryotes.

Acknowledgements. We thank the captain and crew from Cruise MR08-04 of RV 'Mirai' for their help in collecting samples and the technicians from Global Ocean Development and Marine Works Japan for sample collection and analysis. Y. Kuroki participated in helpful discussions. We deeply appreciate the excellent technical help provided by Drs. T. Yokokawa (Ehime University, Matsuyama, Japan) and M. Uchimiya (University of Tokyo, Kashiwa, Japan). This work was partially supported by a Grant-in-Aid for Scientific Research (B) (20310004) from the Japan Society for the Promotion of Science.

\section{LITERATURE CITED}

Alonso-Sáez L, Sánchez O, Gasol JM, Balagué V, PedrósAlio C (2008) Winter-to-summer changes in the composition and single-cell activity of near-surface Arctic prokaryotes. Environ Microbiol 10:2444-2454

> Amann RI, Binder BJ, Olson RJ, Chisholm SW, Devereux R, Stahl DA (1990) Combination of 16S rRNA-targeted oligonucleotide probes with flow cytometry for analyzing mixed microbial populations. Appl Environ Microbiol 56: 1919-1925

Bano N, Ruffin S, Ransom B, Hollibaugh JT (2004) Phylogenetic composition of Arctic Ocean archaeal assemblages and comparison with Antarctic assemblages. Appl Environ Microbiol 70:781-789

> Brochier-Armanet C, Boussau B, Gribaldo S, Forterre P (2008) Mesophilic crenarchaeota: proposal for a third archaeal phylum, the Thaumarchaeota. Nat Rev Microbiol 6:245-252

> Carmack EC, Aagaard K, Swift JH, MacDonald RW and others (1997) Changes in temperature and tracer distributions within the Arctic Ocean: results from the 1994 Arctic Ocean section. Deep-Sea Res II 44:1487-1502

> Christman GD, Cottrell MT, Popp BN, Gier E, Kirchman DL (2011) Abundance, diversity, and activity of ammoniaoxidizing prokaryotes in the coastal Arctic Ocean in summer and winter. Appl Environ Microbiol 77:2026-2034

> Church MJ, DeLong EF, Ducklow HW, Karner MB, Preston CM, Karl DM (2003) Abundance and distribution of planktonic Archaea and Bacteria in the waters west of the Antarctic Peninsula. Limnol Oceanogr 48:1893-1902

> DeLong EF (1992) Archaea in coastal marine environments. Proc Natl Acad Sci USA 89:5685-5689
DeLong EF, Taylor LT, Marsh TL, Preston CM (1999) Visualization and enumeration of marine planktonic archaea and bacteria by using polyribonucleotide probes and fluorescent in situ hybridization. Appl Environ Microbiol 65:5554-5563

DeLong EF, Preston CM, Mincer T, Rich V and others (2006) Community genomics among stratified microbial assemblages in the ocean's interior. Science 311:496-503

Frigaard NU, Martinez A, Mincer TJ, DeLong EF (2006) Proteorhodopsin lateral gene transfer between marine planktonic Bacteria and Archaea. Nature 439:847-850

Fuhrman JA, McCallum K, Davis AA (1992) Novel major archaebacterial group from marine plankton. Nature 356:148-149

> Galand PE, Lovejoy C, Vincent WF (2006) Remarkably diverse and contrasting archaeal communities in a large arctic river and the coastal Arctic Ocean. Aquat Microb Ecol 44:115-126

Galand PE, Lovejoy C, Pouliot J, Vincent WF (2008) Heterogeneous archaeal communities in the particle-rich environment of an arctic shelf ecosystem. J Mar Syst 74: 774-782

- Galand PE, Casamayor EO, Kirchman DL, Potvin M, Lovejoy $C$ (2009) Unique archaeal assemblages in the Arctic Ocean unveiled by massively parallel tag sequencing. ISME J 3:860-869

> Garneau ME, Vincent WF, Alonso-Saez L, Gratton Y, Lovejoy C (2006) Prokaryotic community structure and heterotrophic production in a river-influenced coastal arctic ecosystem. Aquat Microb Ecol 42:27-40

> Herfort L, Schouten S, Abbas B, Veldhuis MJW and others (2007) Variations in spatial and temporal distribution of Archaea in the North Sea in relation to environmental variables. FEMS Microbiol Ecol 62:242-257

Herndl GJ, Reinthaler T, Teira E, van Aken H, Veth C, Pernthaler A, Pernthaler J (2005) Contribution of Archaea to total prokaryotic production in the deep Atlantic Ocean. Appl Environ Microbiol 71:2303-2309

Jakobsson M, Macnab R, Mayer L, Anderson R and others (2008) An improved bathymetric portrayal of the Arctic Ocean: implications for ocean modeling and geological, geophysical and oceanographic analyses. Geophys Res Lett 35, doi:10.1029/2008GL033520

Jones EP (2001) Circulation in the Arctic Ocean. Polar Res 20:139-146

> Jones EP, Rudels B, Anderson LG (1995) Deep waters of the Arctic Ocean: origins and circulation. Deep-Sea Res I 42: 737-760

Karner MB, DeLong EF, Karl DM (2001) Archaeal dominance in the mesopelagic zone of the Pacific Ocean. Nature 409:507-510

Kirchman D, Sigda J, Kapuscinski R, Mitchell R (1982) Statistical analysis of the direct count method for enumerating bacteria. Appl Environ Microbiol 44:376-382

> Kirchman DL, Elifantz H, Dittel AI, Malmstrom RR, Cottrell MT (2007) Standing stocks and activity of Archaea and Bacteria in the western Arctic Ocean. Limnol Oceanogr 52:495-507

Könneke M, Bernhard AE, de la Torre JR, Walker CB, Waterbury JB, Stahl DA (2005) Isolation of an autotrophic ammonia-oxidizing marine archaeon. Nature 437:543-546

Massana R, Murray AE, Preston CM, DeLong EF (1997) Vertical distribution and phylogenetic characterization of marine planktonic Archaea in the Santa Barbara Channel. Appl Environ Microbiol 63:50-56 
Nishino S, Shimada K, Itoh M, Yamamoto-Kawai M, Chiba S (2008) East-west differences in water mass, nutrient, and chlorophyll a distributions in the sea ice reduction region of the western Arctic Ocean. J Geophys Res 115: C00A01, doi:10.1029/2007JC004666

Pernthaler A, Pernthaler J, Amann R (2002a) Fluorescence in situ hybridization and catalyzed reporter deposition for the identification of marine bacteria. Appl Environ Microbiol 68:3094-3101

Pernthaler A, Preston CM, Pernthaler J, DeLong EF, Amann R (2002b) Comparison of fluorescently labeled oligonucleotide and polynucleotide probes for the detection of pelagic marine bacteria and archaea. Appl Environ Microbiol 68:661-667

Schattenhofer M, Fuchs BM, Amann R, Zubkov MV, Tarran GA, Pernthaler J (2009) Latitudinal distribution of prokaryotic picoplankton populations in the Atlantic Ocean. Environ Microbiol 11:2078-2093

Shimada K, Carmack EC, Hatakeyama K, Takizawa T (2001) Varieties of shallow temperature maximum waters in the Western Canadian Basin of the Arctic Ocean. Geophys Res Lett 28:3441-3444, doi:10.1029/ 2001GL013168

Teira E, Reinthaler T, Pernthaler A, Pernthaler J, Herndl GJ (2004) Combining catalyzed reporter deposition-fluores-

Editorial responsibility: Gerhard Herndl, Vienna, Austria cence in situ hybridization and microautoradiography to detect substrate utilization by bacteria and Archaea in the deep ocean. Appl Environ Microbiol 70:4411-4414

Teira E, Lebaron P, van Aken H, Herndl GJ (2006) Distribution and activity of Bacteria and Archaea in the deep water masses of the North Atlantic. Limnol Oceanogr 51: 2131-2144

Ter Braak CJF (1986) Canonical correspondence analysis: a new eigenvector technique for multivariate direct gradient analysis. Ecology 67:1167-1179

Wallner G, Amann R, Beisker W (1993) Optimizing fluorescent in situ hybridization with ribosomal-RNA-targeted oligonucleotide probes for flow cytometric identification of microorganisms. Cytometry 14:136-143

Wells LE, Deming JW (2003) Abundance of Bacteria, the Cytophaga-Flavobacterium cluster and Archaea in cold oligotrophic waters and nepheloid layers of the Northwest Passage, Canadian Archipelago. Aquat Microb Ecol 31:19-31

> Wessel P, Smith WHF (1991) Free software helps map and display data. Eos Trans AGU 72:441-446, doi:10.1029/ 90EO00319

- Wessel P, Smith WHF (1998) New improved version of Generic Mapping Tools released. Eos Trans AGU 79:579, doi:10.1029/98EO00426

Submitted: January 23, 2012; Accepted: March 3, 2013

Proofs received from author(s): April 20, 2013 